\title{
1
}

\section{Introduction: The Cold War in the Classroom International Perspectives on Textbooks and Memory Practices}

\section{Barbara Christophe}

Recalling the past has been described as an 'unnatural act', involving as it does a constant oscillation between two opposing but equally indispensable modes of defining the relation between times past and times present (Wineburg 1999). Similarities as well as differences are highlighted in one moment and rendered invisible in another. Complementing as much as constraining each other, these two approaches create familiarity and strangeness, proximity and distance in an almost paradoxical manner. Both have their own merits. While the vague idea of sharing a common identity with those who preceded us in time awakens our interest in the past, grasping the differences between the way we feel, think and act and the way people of former times did so enables us to understand the contingency of our own perceptions of and performances in the world (Wineburg 1999, 490).

B. Christophe $(\bowtie)$

Georg Eckert Institute for International Textbook Research, Member of the Leibniz Association, Brunswick, Germany e-mail: christophe@gei.de 
What appears to be the normal if somewhat ambitious script for most of our encounters with the past turns into a rather complex matter when it comes to calibrating the relationship between the Cold War past and the post-Cold War present. We are faced with at least two challenges. On the one hand, we have competing definitions of the present moment as the indispensable starting point for our reconstructions of the past. On the other, we have multiple ways of establishing a link between what is now and what was then. Some observers perceived $9 / 11$ as the trigger moment of a new fundamental clash, a 'long war' between the West and Islam, the new antagonist that has replaced the former East (Buzan 2006). For others, Russia's annexation of Crimea in 2014 signalled a return to the familiar constellation of polarised conflict between East and West (Legvold 2014; Ciolan 2016). At the same time, various commentators have repeatedly invoked the end of the Cold War since 1990. While the East-West rivalry was seen to have abated through a sweeping and glorious victory of the West in the 1990s, recent discourses herald the eclipse of the same West in the light of mounting tensions between Europe and the USA (Kimmage 2013; Wright 2017). Without doubt, current claims of an insurmountable abyss separating the days of the Cold War from our present times has gained in plausibility with the lessthan-predictable policies of President Trump towards Russia. The complex realities of today's world in which the current leader of the USA ponders publicly about accepting Russia's take-over of Crimea one moment while commanding air strikes in Syria and thus risking a military confrontation with the same Russia the next (Rutland 2017), could not contrast more sharply with the ritualised and predictable opposition between the former superpowers that dominated international politics from 1947 to 1990.

Memory theory teaches us that present moments always leave their imprint on the many different and ultimately contingent ways in which the past can be reconstructed. The current situation of uncertainty and unpredictability therefore could not but provoke a controversy on how to make sense of the Cold War. Indeed, contrary to claims according to which the end of the East-West rivalry and the opening of Soviet archives would lead to a lessening of controversies (Nehring 2012), we observe a multiplication of debates. It is not only that traditionalist, revisionist and 
post-revisionist frames, which either blame the USSR, the USA or both for having caused the conflict, still vie for hegemony (Lundestad 2014); the question as to whether the second half of the $20^{\text {th }}$ century has been shaped more profoundly by the East-West or the North-South conflict has also triggered hot debate (Iriye 2013). On a more fundamental level, we even hear the argument that the USA and the USSR, both of which tried to change the outlook of the world according to their own images (Westad 2000; Engerman 2010; Duara 2011) shared several crucial features despite the ritualised stand-off they were staging. Finally, historians are in dispute about the true nature of the Cold War. While some point to the ever-present fear of dying in a nuclear war as the defining moment (Nehring 2012), others identify the social welfare state as a by-product of the conflict (Kaelble 2011).

The authors of this book do not engage directly in these debates but rather aim to analyse empirically to what extent practices of remembering the Cold War in history textbooks and in the social space of the history classroom are informed by the various viewpoints and positions circulating in academic and public discourses. This agenda results from conceptual decisions taken on four levels.

First, approaching the Cold War from an angle informed by memory studies and raising the question of how its unavoidably selective and thus political image is produced nowadays, the volume simultaneously addresses - and moves beyond - recent trends in Cold War studies. While historians have shown an increased interest in the cultural dimension of the Cold War as a phenomenon of the past for some time, looking at the roles played by different media as well as networks of people and organisations in reproducing the binary oppositions on which the conflict was based (Sanders 2000, Vowinckel et al. 2012), only scant and unsystematic attention (Lowe/Joel 2012, Jarausch et al. 2017) has been paid to processes of negotiating its meaning in the present. At the same time, memory studies have been largely preoccupied with exploring the more settled memory of the Second World War or the Holocaust. According to the authors of this book, shifting the focus to a more contested issue like the Cold War makes it simultaneously more compelling and rewarding to investigate which of the manifold events of the past are referred to in concrete acts of remembering. 
Second, in dealing with practices of remembering the Cold War in their manifold forms and diverse facets, the authors of this book intend to bridge practice theory and memory studies. Although practice theory is a rather heterogeneous field stretching from classics like Giddens and Bourdieu to actor-network theories, two crucial ideas serve as a common denominator among various approaches. Practices are not only perceived to be a hinge between the situated actions of concrete individuals and the cultural structures that imbue these actions with a certain dose of predictability without fully determining them (Pentzold 2015); they are also seen as being based on practical knowledge that usually remains implicit, thus allowing for a certain degree of vagueness and ambivalence (Reckwitz 2003). Applying these assumptions to the study of social processes of negotiating the meaning of the Cold War, we emphasise that individual acts of remembering are shaped by collectively shared patterns of ascribing meaning to selected facts of the past considered relevant to today's memory. At the same time, however, we also admit that these patterns are embodied in usually rather polysemic texts, artefacts or performances (Sturken 1997, Sandage 1993), which do not have a life of their own beyond being reiterated, recollected and at times reshaped or reconfigured by concrete individuals (Olick/Robinson 1998, 111; Feindt et al. 2014, 30). Instead of reifying the difference between individual and collective memory, which ultimately constitutes two ways of looking at the same thing, we focus on disentangling the many different factors that play out in the concrete, situated acts of recalling the past that we call memory practices. We moreover construe these memory practices as activities that, to a certain extent, are a matter of sheer routine. We thus claim that our encounters with the past are not only shaped by conscious decisions regarding what to remember and what to forget; they are also driven by the silent work of common-sense assumptions and the binary oppositions these support. Conceiving of memory practices as based to a large degree on implicit knowledge, we thus attend to the messiness and ambivalence deemed characteristic of practices in general (Goodnough 2008), and of practices of recalling the Cold War past in particular, given not only the disputes around that period but also the postmodern trend towards chaotic, fragmentary and free-floating memories (Huyssen 1995). 
Third, all authors have chosen to analyse social practices of negotiating the meaning of the Cold War in the institutional field (Schudson 1992) of the school, focusing on textbooks, teachers and students. Observing memory practices through these analytical lenses comes with several advantages. History textbooks are a mass medium for the dissemination of officially approved images of history and, at the same time, mirrors of societal controversies surrounding sensitive issues (Klerides 2010; Macgilchrist 2015). They mingle and blend myriads of discursive threads which connect them with the wider social environment (Binnenkade 2015). Situated at the boundaries between politics, history scholarship and pedagogy, they reflect curricular demands as well as scientific and pedagogic standards. They respond to market requirements and to political debates. History teachers are members of a state elite specialised in conveying official interpretations, while, at the same time, each teacher carries a unique autobiographical memory (Christophe 2012; Umetbaeva 2015). Like their students, they read newspapers and novels, watch films, browse the internet and talk with family and friends, thus bringing numerous mediated memories into the interactional space of the classroom. As the addressees of contradictory expectations, pupils are required to reproduce interpretative knowledge and, at the same time, develop interpretative autonomy (Spär/Sperisen 2010). Furthermore, they are not only future citizens who are supposed to adopt officially sanctioned knowledge; they are also the offspring of families and social milieus with their own potentially diverging memories (Welzer/Moller/Tschuggnall 2002). Textbook discourse, teacher-talk and classroom practice are thus firmly embedded in a wide range of social relations stretching far beyond them. The insights to be gained from their analysis can therefore be expected to be relevant for a broader social context. Being entangled in structural ambivalences, they can moreover be assumed to produce the ambivalence and contingency which practice theory is especially well equipped to address.

At the same time, a focus on the school proves illuminating when examining current trends in the field of memory research. Some of our authors respond to the increased interest in the generational transmission of memory (Palmberger 2016) by either analysing textbooks from a diachronic perspective or by exploring how the meaning of the past is nego- 
tiated between teachers and students as members of different generations with particular common-sense assumptions and exposure to varying media discourses. Most of the contributions resonate well with the new focus within memory research on conflict and contestation (Schwartz 2016). Some give special emphasis to ambivalences in textbooks in order to detect cracks and fissures in mnemonic hegemonies. Others approach the classroom as a social space where unresolved mnemonic disputes, often hidden behind vague phrases (Ryan 2011), are likely to bubble to the surface when students, as newcomers to their respective memory cultures, have not yet fully internalised the social rules of navigating precarious issues relating to the past.

Fourth, approaching the history classroom with a focus on memory practices, most authors move beyond analyses of learning and teaching practices. Whereas previous studies have been primarily interested in practices of history education, exploring which teaching strategies would be most effective in producing desired learning outcomes or asking how one can help students best master historical thinking (Wineburg 2001; Van Drie \& Van Boxtel 2008), the majority of contributions to this volume look into memory practices in history education. The focus is not on history as a discipline, requiring certain ways of doing and saying, but rather on history education as a setting in which we can closely observe how teachers and students 'do memory' (Macgilchrist et al. 2015) and engage with the past. Emphasis is given to decisions taken on the level of content rather than teaching or learning strategies. We want to know which facts attract the attention of teachers and students and which are ignored by them. We explore which interpretations are guarded and which are rejected or simply sidelined. Attending to all these choices, we are interested in the political (Sturken 2008, 74) and not in the didactic implications that follow from them. Approaching the history classroom from the memory practices angle and thus emphasising the role of implicit knowledge and routines in our dealings with the past, we also introduce new aspects into a debate that has so far been mainly focussed on historical consciousness (Seixas 2004). While this term seems to imply that teachers and students are as a rule highly reflective when they 'do' history, the contributions to this book show that doing history is essentially not much different from doing memory. Neither can avoid taking a 
stance, and neither can escape being informed by social discourses with all their common-sense assumptions and categorisations which are, as a rule, not objects of conscious reflection and are thus all the more powerful.

The volume is divided into three sections, which (i) look at interpretations of the Cold War offered in textbooks, (ii) draw on teachers' understanding of textbooks and (iii) analyse how textbooks, teachers and students interact with one another in the setting of the history classroom. The chapters in the first section investigate to what extent narratives conveyed in educational media reproduce, destabilise or creatively appropriate current discourses in historiography and politics. Taking into account the particular challenges faced by practices of remembering the Cold War in times of unstable political identities, most chapters also emphasise the ambivalences and tensions built into these narratives as well as the strategies designed to deal with them. Based on interviews and observational data, the contributions to the second and third sections not only ask how teachers and students position themselves towards social discourses; they also explore how ways of remembering the Cold War can be informed by situational dynamics between interviewer and interviewee or by the expectations placed on teachers and students alike. Despite these variations in the breadth and depth of their empirical basis, and despite the peculiarity of the analytical questions they raise, all contributions share one crucial feature: All focus on rendering explicit what is often only implied in written texts or in verbal statements.

In terms of geographical scope, studies on textbooks, teacher-talk and classroom interaction in Germany, Sweden and Switzerland form the core of the book. These three countries not only happened to be at the focus of the international research projects on which the volume is based; all of them assumed diverging roles during the Cold War past. While Germany was divided into two states, each at the frontline of the Cold War and thus closely involved in the respective political and/or military alliances, Sweden and Switzerland demonstrated two varieties of neutral policy. In the case of Switzerland this followed a more pragmatic and calculated course, at the same time affirming western values (Wenger and Nuenlist 2008), while the Swedish variant followed the moral pledge for a 'Third Way' (Aselius 2005; Browning 2007). Against this backdrop, the 
contributions to this volume explore how these different constellations of the past inform memory practices in the present.

Case studies focusing exclusively on textbooks further enrich the comparative angle. They treat the USA and Russia as the main protagonists of the conflict, as well as Poland and Belgium as countries located on different sides of the iron curtain. They further analyse textbooks from China as the new aspiring hegemonic power, and Cold-War narratives from Chile and South Africa, both of which were part of the so-called former 'Third World'. To sum up, the chapters of this book provide rich descriptions of specific acts of recalling the contested Cold War past in the social space of the school. Covering a broad range of cultural contexts and applying a diverse set of methodological strategies, they map the dividing lines in and between memory cultures in the crisis-driven and volatile age of our present in which mnemonic consensus is clearly an issue of the past - if indeed it has ever existed at all. The authors point to varying degrees of ambivalence, vagueness and contradictions in the inescapably political textbook narratives understood to be echoes of societal and academic controversies. Authors focussing on teachers and the history classroom show how unresolved political issues create tensions and dilemmas in history education. They render visible how teachers struggle to handle these challenges by pretending that what they do is 'just history'. Obfuscating the political that is inherent to all memory practices, they produce the illusion that the history in which they are engaged is all about addressing the past with a reflexive and disciplined approach.

\section{Bibliography}

Aselius, Gunnar. 2005. 'Swedish Strategic Culture after 1945'. Cooperation and Conflict 40, no. 1: 25-44.

Binnenkade, Alexandra. 2015. 'Doing Memory: Teaching as a Discursive Node'. Journal of Educational Media, Memory, and Society 7, no. 2: 29-43.

Browning, Christopher. 2007. 'Branding Nordicity: Models, Identity and the

Decline of Exceptionalism' Cooperation and Conflict 42, no. 1: 27-51.

Buzan, Barry. 2006. 'Will the Global War on Terrorism be the New Cold War?' International Affairs 82, no. 6: 1101-1118. 
Christophe, Barbara. 2012. 'Verhandlungen über den Sozialismus. Geschichtslehrer als Schnittstelle zwischen individuellem und kollektivem Gedächtnis'. Eckert. Beiträge, no. 1. http://repository.gei.de/handle/11428/102 (last accessed 13 May 2019).

Ciolan, Ionela Maria. 2016. "The Role of the "New Cold War" Concept in Constructing Russia's Great Power Narrative'. CES Working Papers 8, no. 4. Centre for European Studies, Alexandru Ioan Cuza University: 625-647.

Duara, Prasjenit. 2011. 'The Cold War as a Historical Period: An Interpretive Essay'. Journal of Global History 6, no. 3: 457-480.

Engerman, David. 2010. 'Ideology and the Origin of the Cold War'. In The Cambridge History of the Cold War. Volume I.: Origins, edited by Melvyn P. Leffler and Odd Arne Westad, 20-43. Cambridge: Cambridge University Press.

Goodnough, Karen. 2008. 'Dealing with Messiness and Uncertainty in Practitioner Research: The Nature of Participatory Action Research'. Canadian Journal of Education 31, no. 2: 431-458.

Huyssen A. 1995. Twilight Memories: Marking Time in a Culture of Amnesia. New York: Routledge.

Jarausch, Konrad H., Christian F. Ostermann and Andreas Etges, eds. 2017. The Cold War: Historiography, Memory, Representation. Berlin: de Gruyter.

Kaelble, Hartmut. 2011. Kalter Krieg und Wohlfahrtsstaat. Europa 1945-1989. München: C. H. Beck.

Klerides, Eleftherios. 2010. 'Imagining the Textbook: Textbooks as Discourse and Genre', Journal of Educational Media, Memory, and Society 2, no. 1: $31-54$.

Legvold, Robert. 2014. 'Managing the New Cold War'. Foreign Affairs 93, no. 4: 74-84.

Lundestad, Geir. 2014. 'The Cold War in Europe, 1945-1949. Some Old and New Theories about the Cold War'. In East, West, North, South. International Relations since 1945. London/New York: Sage.

Macgilchrist, Felicitas. 2015. 'Geschichte Und Dissens: Diskursives Ringen Um Demokratie in Der Schulbuchproduktion'. In Erziehungswissenschaftliche Diskursforschung: Empirische Analysenzu Bildungs-und Erziehungsverhältnissen, edited by Susann Fegter, Fabian Kessl, Antje Langer, Marion Ott, Daniela Rothe and Daniel Wrana. Wiesbaden: VS Verlag für Sozialwissenschaften. https://doi.org/10.1007/978-3-531-18738-9_10

Nehring, Holger. 2012. 'What Was the Cold War?' The English Historical Review 127, no. 527: 920-949. https://doi.org/10.1093/ehr/ces176 
Palmberger, Monika. 2016. How Generations Remember. Conflicting Histories and Shared Memories in Post-War-Bosnia and Herzegovina. London: Palgrave. Pentzold, Christian. 2015. 'Praxistheoretische Prinzipien, Traditionen und Perspektiven kulturalistischer Kommunikations- und Medienforschung'. Medien \& Kommunikationswissenschaft 63, no. 2: 229-245.

Reckwitz, Andreas. 2003. 'Towards a Theory of Social Practices'. European Journal of Social Theory 5: 245-265.

Rutland, Peter. 2017. 'Trump, Putin and the Future of US-Russian Relations'. Slavic Review 71: 541-556.

Sandage, Scott A. 1993. 'A Marble House Divided: The Lincoln Memorial, the Civil Rights Movement, and the Politics of Memory, 1939-1963'. Journal of American History 80, no. 1: 135-167.

Sanders, Frances Stonor. 2000. The Cultural Cold War: The CIA and the World of Arts and Letters. New York: New press.

Schudson M. 1992. Watergate in American Memory: How We Remember, Forget, and Reconstruct the Past. New York: Basic Books.

Schwartz, Barry. 2016. 'Rethinking the Concept of Collective Memory', in Routledge International Handbook of Memory Studies, edited by Anna Lisa Tota and Trever Hagen, 9-20. London/New York: Routledge.

Seixas, Peter, ed. 2004. Theorizing Historical Consciousness. Toronto: University of Toronto Press.

Sturken, Marita. 1997. Tangled Memories: The Vietnam War, The Aids Epidemic, and the Politics of Remembering. Berkeley: University of California Press.

Sturken, Marita. 2008. 'Memory, Consumerism and Media: Reflections on the Emergence of the Field'. Memory Studies 1, no. 1.

Umetbaeva, Damira. 2015. 'Paradoxes of Hegemonic Discourse in Post-Soviet Kyrgyzstan: History Textbooks' and History Teachers' Attitudes towards the Soviet Past'. Central Asian Affairs 2, no. 3: 287-306.

Van Drie, Janet and Carla Van Boxtel. 2008. 'Historical Reasoning: Towards a Framework for Analyzing Students' Reasoning about the Past'. Educational Psychology Review 20, no. 2: 87-110.

Vowinckel, Annette, Marcus M. Payk and Thomas Lindenberger, eds. 2012. Cold War Cultures. Perspectives on Eastern and Western European Societies. New York/Oxford: Berghahn Books.

Welzer, Harald, Sabine Moller and Karoline Tschuggnall. 2002. 'Opa war kein Nazi. Nationalsozialismus und Holocaust im Familiengedächtnis. Frankfurt a. M: Fischer Taschenbuch Verlag. 
Wenger, Andreas and Christian Nuenlist. 2008. 'A "Special Case" between Independence and Interdependence: Cold War Studies and Cold War Politics in Post-Cold War Switzerland'. Cold War History 8, no. 2: 213-240.

Westad, Odd Arne. 2000. 'The New International History of the Cold War: Three Possible Paradigms'. Diplomatic History 24, no. 4: 551-565.

Wineburg, Sam. 2001. Historical Thinking and other Unnatural Acts: Charting the Future of Teaching the Past. Philadelphia: Temple University Press.

Wright, Thomas. 2017. A Post-American Europe and the Future of US-Strategy, Washington: Brookings/Robert Bosch Foundation.

Open Access This chapter is licensed under the terms of the Creative Commons Attribution 4.0 International License (http://creativecommons.org/licenses/ by/4.0/), which permits use, sharing, adaptation, distribution and reproduction in any medium or format, as long as you give appropriate credit to the original author(s) and the source, provide a link to the Creative Commons licence and indicate if changes were made.

The images or other third party material in this chapter are included in the chapter's Creative Commons licence, unless indicated otherwise in a credit line to the material. If material is not included in the chapter's Creative Commons licence and your intended use is not permitted by statutory regulation or exceeds the permitted use, you will need to obtain permission directly from the copyright holder.

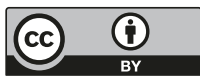

